\title{
Study of the Geo-Ecological State of Groundwater of Metropolitan Areas under the Conditions of Intensive Contamination Thereof
}

\author{
Yana Lebedeva ${ }^{1 *}$, Pavel Kotiukov ${ }^{1}$, Ivan Lange ${ }^{1}$ \\ 1 Department of Hydrogeology and Engineering Geology, Saint-Petersburg Mining University (University of \\ Mines), 21st Line of the Vasilevsky Island, 2, 199106, Saint Petersburg, Russia \\ * Corresponding author's e-mail: pavel_spmi@mail.ru
}

\begin{abstract}
The paper presents the analysis of the geo-ecological state of groundwater within an urban territory on the example of Saint Petersburg. The paper considers two key sites, characterized by different levels of contamination of the underground environment (Primorsky and Krasnogvardeisky districts of Saint Petersburg) and provides an assessment of the main natural and man-made sources of the groundwater contamination within the territory of the selected districts. The composition of groundwater was studied in the zones with different pattern of contamination (cemeteries, liquidated landfills, industrial areas, etc.). The negative impact of the man-made sources of contamination on the state of groundwater was determined. The recommendations for arranging hydrogeological groundwater monitoring in metropolitan areas were developed.
\end{abstract}

Keywords: contamination, groundwater, man-made sources, Primorsky and Krasnogvardeisky districts, changes in chemical composition, monitoring

\section{INTRODUCTION}

The current situation with urban infrastructures operation is characterized in that their geoecological state is considered very unfavorable, which is determined by the pattern and duration of the man-made impact. It is known that the assessment of the geo-ecological conditions within the territory of the Russian Federation should be carried out according to the recommendations, stipulated by the regulatory document "11-102-97 "Engineering and environmental surveys for construction", according to which it is recommended to study the contamination of cities for a period of up to 40-50 years, sometimes for a longer period of time to allocate the sites of the presently liquidated industrial enterprises, leaks from watercarrying facilities, breakthroughs of wastewater sewers, accidental emissions, the use of chemical fertilizers, etc. [4]. Moreover, the practice of studying the geo-ecological state of metropolitan areas on the example of Saint Petersburg, has proven the need to analyze their contamination not only over the past decades or from the moment of their foundation, but even earlier [5].

\section{MATERIALS AND METHODS}

The history of developing modern Saint Petersburg exceeds 300 years and is associated with its foundation. However, numerous studies by the scientists of the Department of Hydrogeology and Engineering Geology of the St. Petersburg Mining University, supervised by prof. R.E. Dashko, revealed that even before the foundation of Saint Petersburg, more than 61 burial sites were located within its territory (fig.1), [10]. In total, according to prof. R.E. Dashko, the history of developing the city area includes several stages of its contamination, taking into account the long period of the development. Thus, since before the foundation of the city, in the $12-16^{\text {th }}$ centuries, the Neva river coastal territories were used for the agricultural needs. Later, in the $17^{\text {th }}$ century, the area of the developing gradually expanded, and, accordingly, 


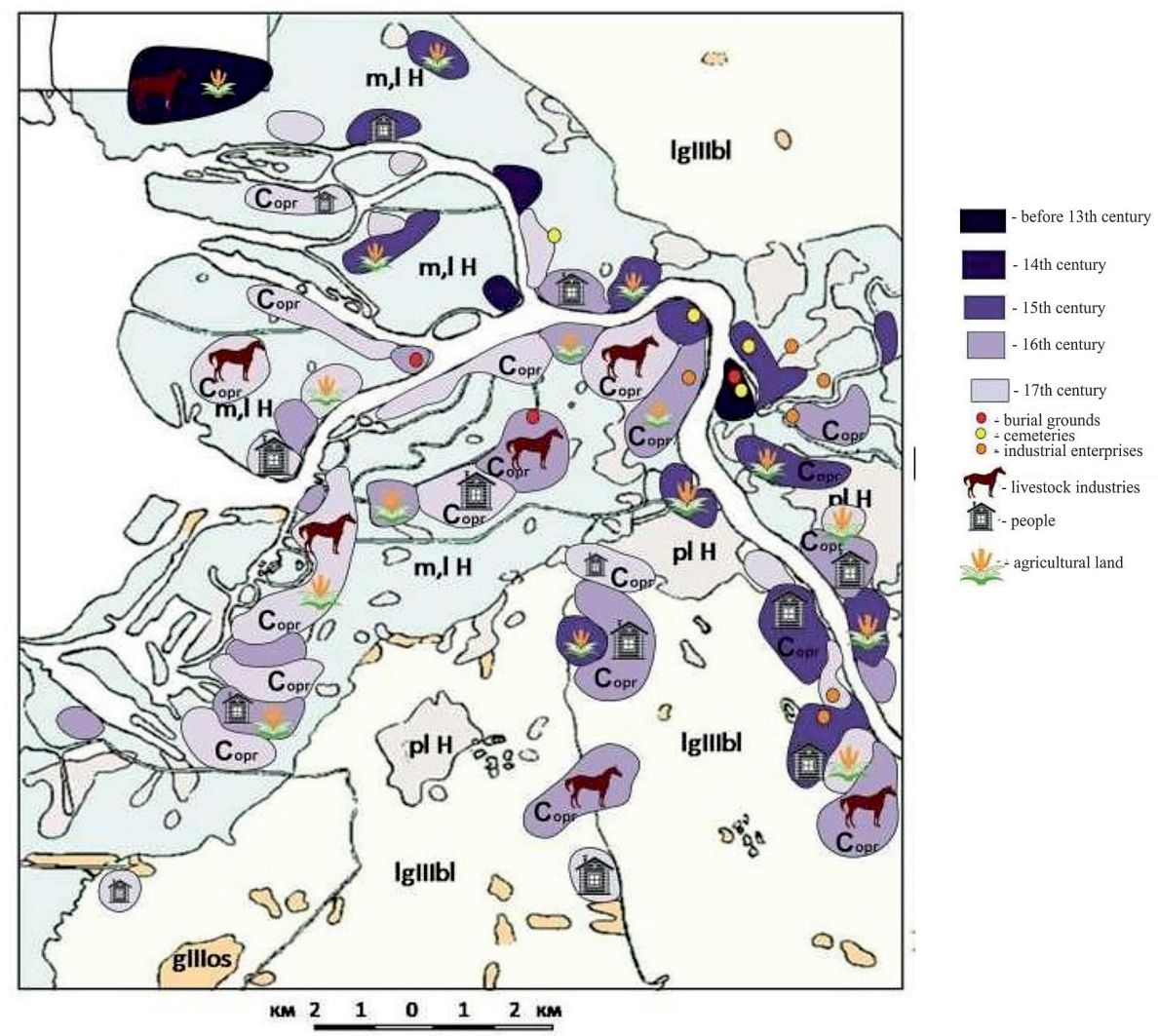

Figure 1. Schematic map of the use of the territory of the Neva river delta before St. Petersburg foundation [10]

the territory contamination, associated with the foundation of the Swedish city of Nien, increased as well. During this period, the most developed areas were the eastern and southern shores of Koivisaari Island (Petrogradsky Island), the eastern part of Hirvisaari Island (Vasilyevsky Island), the northeastern part of Usadis (Admiralteysky Island) and Pervushkin (Kazansky and Spassky Islands) Islands. At the beginning of the $18^{\text {th }}$ century, the pattern of contamination already had a regional character, associated with the foundation and growth of the city. Later, the geo-ecological situation of the underground space of Saint Petersburg has undergone significant degradation with the development of the industrial production, in the absence of a water disposal system, in the presence of multiple landfills for household waste as well as buried hydrographic network facilities, and due to the impact of the existing and liquidated cemeteries [10].

Currently, the contamination of metropolitan areas causes immense damage to the underground space, which first of all affects the color, the color of soils changes from brownish to grayish-greenish, the composition, state and physic-mechanical properties of soils and sandy-clayey soils, resulting in a decrease in their strength and an increase in compressibility $[15,20]$. In addition, the unfavorable geo-ecological situation with the underground space of the metropolitan area affects the composition of groundwater, resulting in an increase in the amount of contaminating compounds $\left(\mathrm{NH}_{4}^{+}\right.$, petroleum hydrocarbons, chlorides, sulfates, hydrogen sulfide), an increase in mineralization, etc., their corrosive effect on structural materials increases as well; the active growth of the underground microbiota of aerobic and anaerobic groups is also intensified. Moreover, an increase in the generation of biochemical gas, the release of which is recorded within the entire large city of Saint Petersburg, is observed as well $[6,8]$.

Recently, in the territory of the city, the Committee for Nature Use, Environmental Protection and Ecological Safety of Saint Petersburg introduced a complex system for monitoring the state of atmospheric air, soil, vegetation, surface and groundwater $[2,12]$. Having conducted the detailed analysis of the obtained data, it was revealed that the state of groundwater is not a matter of adequate consideration. The study on the underground hydrosphere includes the following: "...the presence of water-bearing horizons; conditions of occurrence, distribution and natural 
protection thereof; composition, filtration and sorption properties of soils of the aeration zone and water-bearing rocks; the presence of top water; the depth of occurrence of the first from the surface water confining stratum; the patterns of groundwater movement, conditions of their supply and discharge, the mode, the presence of a hydraulic connection between horizons and with surface waters; the chemical composition of groundwater, its contamination by harmful components and the possibility to affect the living conditions of the population..." [4]. It is worth noting that the composition of water is estimated by the content of macro-components: calcium, magnesium, sodium, potassium, bicarbonates and carbonateions, sulfate-ions, chloride-ions, as well as of dry residue, biogenic elements (nitrogen, in the form of nitrite-ions, nitrate- ions and ammonium ion), iron, dissolved gases (hydrogen sulfide and carbon dioxide); in turn, the presence of organic substances is estimated by means of indirect parameters - permanganate oxidation, sometimes by chemical oxygen demand [1]. The plan of observations in combination with a general hydrochemical research includes the determination of specific priority contaminating agents, entering groundwater (oil products, phenols, heavy metals - lead, cadmium, mercury, etc.). It is worth noting that most contaminating agents are unstable; after sampling in the field environment and before the laboratory testing, they may be completely missing $\left(\mathrm{H}_{2} \mathrm{~S}, \mathrm{NH}_{4}^{+}\right)$. This phenomenon is determined by the time interval between sampling and the date of the chemical analysis of water, as well as by the difference in physicochemical and biochemical environments $[5,16]$.

It should be understood that studying the hydro-chemical mode of groundwater allows assessing the changes in the intensity of the manmade impact and in the composition of the introduced components [3, 17]. The groundwater horizon, to a greater extent, serves as an indicator of specific features and pattern of the territory contamination due to the absence of an overlapping water confining stratum and to the presence of a direct connection with precipitation, leaks, surface watercourses and water bodies $[9,13]$.

The ground water-bearing horizon is developed within the entire territory of Saint Petersburg, except for the areas used as enclosure structure for pits or embankments. The state of groundwater is subjected to continuous monitoring.
Currently, the regional network comprises 51 monitoring wells.

\section{RESULTS AND DISCUSSION}

In order to perform a comparative assessment of the chemical composition of groundwater, several key sites in the northern part of the city, being subjected to active developing by building modern residential houses and complexes: Primorsky and Krasnogvardeisky districts were selected as the objects of study. The sites are characterized by different environmental situation. Thus, according to the general ranking of districts, the Primorsky district is considered as one of the most favorable and uncontaminated areas with respect to the condition of soils, surface watercourses and water bodies, green zones and atmospheric air, while the Krasnogvardeisky district, on the contrary, is considered as a highly contaminated area.

The Primorsky district is located in the northwestern part of Saint Petersburg, with an area of more than $109 \mathrm{~km}^{2}$. The district takes a leading position as to environmental position compared to other districts of the city. Green zones occupy more than $25 \%$ of the district territory. The district includes a large area of special conservation interest - Yuntolovsky regional nature reserve with an area of $7.1 \mathrm{~km}^{2}$, Udelny Park $-1.5 \mathrm{~km}^{2}$, Park of the $300^{\text {th }}$ Anniversary of Saint Petersburg $-0.56 \mathrm{~km}^{2}$, as well as many other green zones.

For the purposes of the study of groundwater composition, the data, obtained from 12 engineering-geological wells in various zones of the Primorsky district, showed that the water-bearing horizon of groundwater, herein presented everywhere, is confined to sandy, sand and sand-gravel varieties, as well as to peat and man-made deposits. The composition and physicochemical conditions of groundwater are formed not only due to the atmospheric precipitation and the presence of buried and active swamps, but also due to the man-made factors: leaks from water disposal systems, infiltration of the liquid phase of the waste from landfills and cemeteries, as well as industrial wastes of enterprises with wet process conditions, etc. (Fig. 2). It is worth noting that the stagnant ground-water conditions are determined by the presence of impermeable structures of embankments, rivers and canals, which are considered potential areas of groundwater draining. 


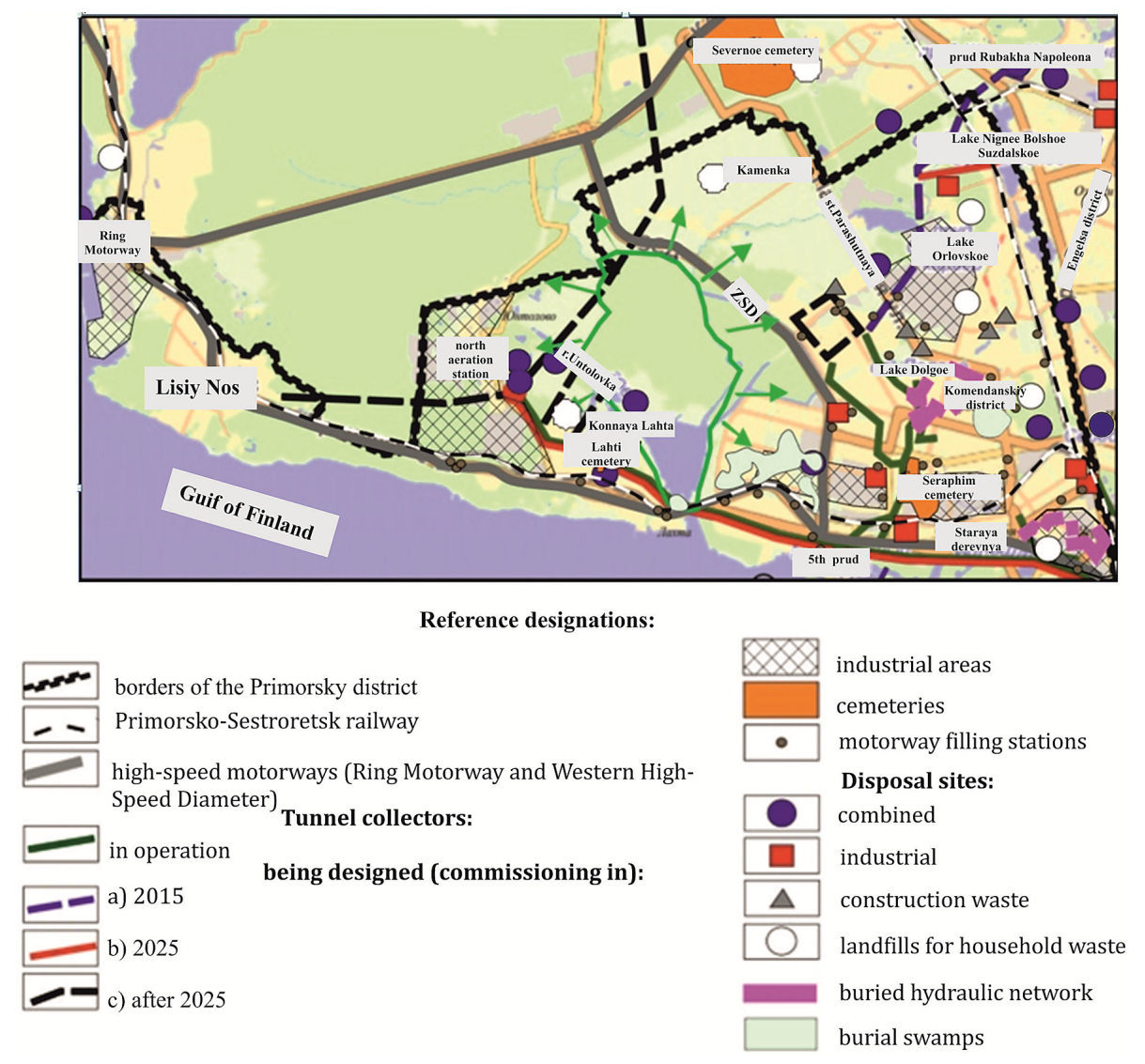

Figure 2. Schematization of the main sources of transformation physical and chemical conditions in the underground space

Within the district territory, the groundwater outside the zones of the man-made impact has a sodium bicarbonate composition with a mineralization of $0.1-0.5 \mathrm{~g} / \mathrm{dm}^{3}$ (fresh). The $\mathrm{pH}$ varies from 7 to 7.5 ; however, in the areas of swamps frequently does not exceed 6.8. It is worth noting that within the developed part of the district, due to intensive contamination, the mineralization value can reach $3 \mathrm{~g} / \mathrm{dm}^{3}$. Moreover, active contamination by organic compounds results to the formation of reducing conditions $(\mathrm{Eh}<0 \mathrm{mV})$, which facilitate the migration of heavy metals, as well as the accumulation of toxic substances [6, 18].

It is interesting to note that although the district as a whole is considered the most favorable in terms of the environmental situation, the results of the chemical analysis of groundwater allows to reveal the presence and significant content of the main contaminating agents, the maximum concentrations of which were recorded in the areas adjacent to the industrial zones and sites containing landfill masses (Table 1, Fig. 2) [5, 14]. They are characterized by high content of chlorine ions, sulfate-ions and ammonium ions, as well as permanganate oxidation.
In the area of the reclaimed landfill, the groundwater also is characterized by a high content of sulfates, which can also be a product of the activity of sulfate-reducing bacteria $[11,19]$. According to the studies by prof. Dashko R.E., the sulfates under anaerobic conditions of Saint Petersburg are reduced to hydrogen sulfide, which facilitates the aquatic acidification and increases its aggressiveness relative to structural materials. In addition, a significant content of permanganate oxidation, as an indicator of the presence of easily oxidized organic substances, is contained in the water samples, taken from the area of contaminated sites. It is worth noting that the low content of ammonium ion within the forest-park zone may be associated with the local placement of landfills.

The Krasnogvardeisky district, located in the northeastern part of Saint Petersburg, with an area of $58 \mathrm{~km}^{2}$, was chosen as the second key site. The district is considered one of the most contaminated in the city. The green zones here account for less than $11 \%$. The district territory comprises Polyustrovsky Park, with an area of $0.4 \mathrm{~km}^{2}$, Park Malinovka $-0.14 \mathrm{~km}^{2}$, etc. 
Table 1. Content of the main components in the groundwater of the Primorsky district in various territories

\begin{tabular}{|c|c|c|c|c|c|c|c|c|c|c|c|c|}
\hline Analyzed & & & II & III & I & J & V & & & VII & VIII & $\begin{array}{l}\text { MCL (sanitary } \\
\text { rules and }\end{array}$ \\
\hline $\mathrm{Ca}^{2+}, \mathrm{mg} / \mathrm{dm}^{3}$ & 10.0 & 4.0 & 32.0 & 34.0 & 240.0 & 152.0 & 238.5 & 168.3 & 50.1 & 88 & 44.0 & - \\
\hline $\mathrm{Mg}^{2+} \mathrm{mg} / \mathrm{dm}^{3}$ & 7.3 & 8.5 & 3.6 & 40.1 & 38.9 & 68.1 & 118.0 & 49.9 & 63.2 & 49.2 & 19.5 & 50 \\
\hline $\mathrm{Na}^{+}+\mathrm{K}^{+}, \mathrm{mg} / \mathrm{dm}^{3}$ & 34.5 & 45.9 & 173.0 & 199.5 & 410.2 & 98.4 & 411.6 & 274.4 & 124.4 & 147.3 & 121.6 & 200 \\
\hline $\mathrm{SO}_{4}^{2-}, \mathrm{mg} / \mathrm{dm}^{3}$ & 18.1 & 38.3 & $\underline{212.3}$ & 239.1 & $\underline{672.4}$ & 280.6 & 226.2 & 48.0 & 6.0 & 63.1 & 153.9 & 500 \\
\hline $\mathrm{Cl}^{-}, \mathrm{mg} / \mathrm{dm}^{3}$ & 21.3 & 28.4 & 14.2 & 56.7 & $\underline{326.2}$ & 85.1 & 284.3 & 245.9 & 341.2 & 164.7 & 134.8 & 350 \\
\hline $\mathrm{HCO}_{3} ; \mathrm{mg} / \mathrm{dm}^{3}$ & 128.1 & 79.3 & 231.8 & 536.8 & 646.6 & 579.8 & 1632.8 & 1006.8 & 567.3 & 531.2 & 195.2 & - \\
\hline $\mathrm{NO}_{3}, \mathrm{mg} / \mathrm{dm}^{3}$ & 5.8 & 7.5 & 8.7 & 8.7 & 12.8 & 4.1 & 1.1 & trace & - & - & 6.1 & 45 \\
\hline $\mathrm{NO}_{2}-\mathrm{mg} / \mathrm{dm}^{3}$ & 0.0 & 0.1 & 0.4 & 0.0 & 0.0 & - & 0.0 & abs. & - & - & 0.0 & 3.0 \\
\hline $\mathrm{NH}_{4}^{+}, \mathrm{mg} / \mathrm{dm}^{3}$ & 3.4 & 37.0 & $\underline{54.0}$ & 25.9 & $\underline{10.9}$ & 6.4 & 5.4 & abs. & - & 15 & 21.6 & \\
\hline $\begin{array}{c}\mathrm{Fe}^{2+}+\mathrm{Fe}^{3+}, \mathrm{mg} / \\
\mathrm{dm}^{3}\end{array}$ & 10.5 & 5.3 & 5.6 & 11.3 & 10.2 & 7.7 & 8.9 & 4.5 & 10.0 & 30 & 0.5 & 0.3 \\
\hline $\begin{array}{l}\text { Dry residue, mg/ } \\
\qquad \mathrm{dm}^{3}\end{array}$ & 119.9 & 136.0 & $\underline{1080.1}$ & 733.6 & $\underline{3370.7}$ & $\underline{1389.7}$ & $\underline{1288.6}$ & 793.9 & $\underline{1077.5}$ & 770.6 & 618.6 & $\begin{array}{l}\text { C.O. } \\
1000\end{array}$ \\
\hline $\begin{array}{c}\text { Total hardness, } \\
\text { mg-eq/dm }\end{array}$ & 1.1 & 0.9 & 1.9 & 5.0 & 15.2 & 13.2 & $\underline{60.5}$ & 35.0 & 21.6 & 20.7 & 3.8 & $7-10$ \\
\hline $\begin{array}{c}\text { Oxidation, } \mathrm{mgO}_{2} / \\
\mathrm{dm}^{3} \text { (perm.) }\end{array}$ & 32.0 & 38.0 & $\underline{121.2}$ & 38.4 & $\underline{412.0}$ & 27.2 & 80.3 & 52.3 & 73.6 & 24.8 & 15.2 & 5.0 \\
\hline$\underset{\mathrm{Cm}^{3}}{\mathrm{CO}_{2} \text { aggres, mg/ }}$ & 11.0 & 33.0 & 0.0 & 4.4 & 22.0 & 5.3 & 13.4 & 5.3 & 2 & 11 & 2.2 & - \\
\hline $\mathrm{pH}$ & 5.8 & 5.3 & 8.6 & 6.6 & 6.6 & 7.1 & 7.3 & 6.2 & 6.8 & 6.4 & 6.8 & $6-9$ \\
\hline
\end{tabular}

Note: I - forest park zone; II - undeveloped territory near the landfill; III - construction site; IV - industrial zone, $\mathrm{V}$ - landfill site after liquidation (the landfill existed for more than 25 years); VI - residential estates in the areas of preexisting swamps; VII - site near the cemetery, VIII - alluvial territory

The chemical composition of groundwater in the pressure-free horizon in the Krasnogvardeisky district was studied by 10 wells. The most important results of the study are presented in Table 2 .

The water-bearing horizon of groundwater, as well as within the Primorsky district, is developed everywhere and is confined to sandy-loam and sandy varieties, as well as biogenic, man-made and marine deposits. The depths of water opening are ranged from 0.5 to $2.0 \mathrm{~m}$. The groundwater supply is carried out due to atmospheric precipitation infiltration, leaks from the water-carrying facilities (water conduits, pressure collectors, sewage pipes) or direct hydraulic connection with the polluted Okhta river (Fig. 3). The groundwater of the Krasnogvardeisky district is characterized by a mixed composition, varying from chloride-bicarbonate sodium-magnesium to sulfate calcium-sodium or sulfate magnesium-calcium due to the intensive contamination of the territory, caused by the wide spreading of industrial zones, existing and liquidated landfills. The $\mathrm{pH}$ value varies from 7 to 7.6 ; in the areas of swamp deposits it does not exceed 6.7. Due to the intensity of contamination, the value of mineralization can increase to $3.5 \mathrm{~g} / \mathrm{dm}^{3}$.

In the considered sites 1 and 2, water has a dark-brown color and technical smell, is characterized by high hardness (14.2-35.0) due to the significant content of alkaline-earth elements: calcium ions - from 80.2 to $274.5 \mathrm{mg} / \mathrm{dm}^{3}$, magnesium ions - from 18.2 to $88.2 \mathrm{mg} / \mathrm{dm}^{3}$. The infiltration of $\mathrm{Ca}^{2+}$ and $\mathrm{Mg}^{2+}$ ions into groundwater may be caused by the fact that aggressive waters facilitate the intensive destruction of fragments of structural materials, pulp present in industrial soils, as well as materials of foundations, preexisting buildings and industrial waste landfills.

Groundwater contamination may also be associated with the increased concentrations of alkaline elements $\left(\mathrm{K}^{+}+\mathrm{Na}^{+}\right)$, which vary within the range from 146.2 to $225.8 \mathrm{mg} / \mathrm{dm}^{3}$. The ions of alkaline elements are present in pulp-and-paper, varnish-and-paint, chemical industries, the plants of which are located along the banks of the Okhta river and annually discharge their wastewater therein, containing high concentrations of sodium. Mineralization varies within a wide range from 1053.7 to $1704.4 \mathrm{mg} / \mathrm{dm}^{3}$. It is worth noting that in some samples, the value of dry residue, obtained with the direct method, slightly exceeded the value of mineralization, which may indicate the presence of volatile organic compounds therein. In order to make the final conclusion on the presence of organic components in water samples and its impact on the composition, direct 



Figure 3. Layout map of the observation network for monitoring the state of groundwater and exogenous geological processes in the territory of the Krasnogvardeisky district [6]

Table 2. The content of the main components in the groundwater of the Krasnogvardeisky district in various territories

\begin{tabular}{|c|c|c|c|c|c|}
\hline \multirow{2}{*}{$\frac{\text { Analyzed elements }}{\mathrm{Ca}^{2+}, \mathrm{mg} / \mathrm{dm}^{3}}$} & \multicolumn{2}{|c|}{ Site 1 Lagody str. } & \multicolumn{2}{|c|}{ Site 2 Magnitogorskaya str. } & \multirow{2}{*}{$\begin{array}{c}\mathrm{MCL} \text { (Sanitary Rules } \\
\text { and Norms) }\end{array}$} \\
\hline & 80.2 & 160.3 & 95.8 & 94.2 & \\
\hline $\mathrm{Mg}^{2+} \mathrm{mg} / \mathrm{dm}^{3}$ & 18.2 & 54.7 & 118.7 & 118.2 & 50 \\
\hline $\mathrm{Na}^{+}+\mathrm{K}^{+}, \mathrm{mg} / \mathrm{dm}^{3}$ & $\underline{216.7}$ & 146.2 & $\underline{225.8}$ & 153.3 & $\underline{200}$ \\
\hline $\mathrm{SO}_{4}^{2-}, \mathrm{mg} / \mathrm{dm}^{3}$ & $\underline{560.5}$ & $\underline{468.3}$ & 185.1 & 163.7 & 500 \\
\hline $\mathrm{Cl}^{-}, \mathrm{mg} / \mathrm{dm}^{3}$ & 35.5 & 30.1 & $\underline{244.7}$ & $\underline{215.6}$ & $\underline{350}$ \\
\hline $\mathrm{HCO}_{3}^{-}, \mathrm{mg} / \mathrm{dm}^{3}$ & 140.3 & 183.1 & $\underline{831.7}$ & $\underline{709.0}$ & $=$ \\
\hline $\mathrm{NO}_{3}^{-}, \mathrm{mg} / \mathrm{dm}^{3}$ & 0.5 & abs. & 0.6 & 0.7 & 45 \\
\hline $\mathrm{NO}_{2}^{-}, \mathrm{mg} / \mathrm{dm}^{3}$ & 0.6 & 0.4 & abs. & no & 3 \\
\hline $\mathrm{NH}_{4}^{+}, \mathrm{mg} / \mathrm{dm}^{3}$ & 1.2 & $\underline{15.6}$ & 0.6 & 0.6 & - \\
\hline $\mathrm{Fe}^{2+}+\mathrm{Fe}^{3+}, \mathrm{mg} / \mathrm{dm}^{3}$ & - & 0.5 & 1.4 & 0.6 & 0.3 \\
\hline Dry residue, $\mathrm{mg} / \mathrm{dm}^{3}$ & 983.4 & 967.6 & 1288.6 & 1101.4 & 1000 \\
\hline Total hardness, mg-eq/dm³ & 15.4 & $\underline{35.0}$ & $\underline{14.5}$ & 14.2 & $\underline{7,4}$ \\
\hline Oxidation, $\mathrm{mgO}_{2} / \mathrm{dm}^{3}$ (perm.) & $\underline{16.4}$ & $\underline{32.4}$ & $\underline{41.0}$ & $\underline{34.5}$ & $\underline{5,4}$ \\
\hline $\mathrm{CO}_{2}$ aggres, $\mathrm{mg} / \mathrm{dm}^{3}$ & 11.0 & 32.7 & no & no & - \\
\hline $\mathrm{pH}$ & 7.3 & 7.1 & 7.6 & 7.6 & $6-9$ \\
\hline
\end{tabular}


distributions of its content by values of COD and $\mathrm{BOD}_{5}$ are required.

The underground water of site 1 also contains an increased amount of sulfates, reaching $468.3-560.5 \mathrm{mg} / \mathrm{dm}^{3}$, the presence of which in some cases may be associated with the discharge of industrial wastewater and household waste into the Okhta river, flowing $125-130 \mathrm{~m}$ from the construction site. The groundwater of site 2 also contains a significant content of chlorine ion, the values of which vary from 215.6 to $244.7 \mathrm{mg} / \mathrm{dm}^{3}$. Infiltration of sulfates and chlorides can take place due to constant leaks from the old sewage system, the replacement of which, within the district territory, is supposed to be implemented before 2025 . As a rule, the sewage drain composition corresponds to the following composition (Table 3, Dashko R.E. 2010).

The groundwater of site 1 contains a high content of ammonium ion, reaching $15.6 \mathrm{mg} / \mathrm{dm}^{3}$, which can enter from an imperfect sewage network or buried dumps, located near the sampling site. It is known that the radius of landfill influence reaches $1 \mathrm{~km}$, sometimes even more. A significant amount of permanganate oxidation was recorded (16.4-41.0 $\left.\mathrm{mgO}_{2} / \mathrm{dm}^{3}\right)$, confirming the presence of easily oxidized organic substances. High permanganate oxidation values result in a shift in the oxidation-reduction potential (Eh) to negative values, which determines the formation of anaerobic conditions in the underground environment. The increased value of free carbon dioxide in groundwater of site 1 in the amount of $92.4-132.0 \mathrm{mg} / \mathrm{dm}^{3}$ witnesses in favor of active microbial activity, since carbon dioxide in water is a respiratory product of microorganisms.

Thus, the study of the component composition of groundwater revealed that - irrespective of the ecological state of the district - groundwater is characterized as highly contaminated.

\section{CONCLUSIONS}

In this regard, the assessment of the geoecological state of groundwater in megalopolises under the conditions of intense pollution of the underground environment should include the following

1. The groundwater within the territories of metropolitan areas with a long period of their development is characterized as highly contaminated, which is determined by the duration and pattern of their contamination (landfills, cemeteries, swamp deposits, etc.).

2 . The contamination of groundwater occurs due to the influence of the natural and man-made sources and facilitates the transformation of the composition of groundwater, resulting in an increase in their aggressiveness relative to structural materials of foundations and supporting structures of underground facilities.

Table 3. The chemical composition of municipal wastewater

\begin{tabular}{|c|c|c|c|c|}
\hline \multirow{2}{*}{ No. } & \multirow{2}{*}{ Analyzed elements } & \multicolumn{2}{|c|}{1} & 2 \\
\hline & & \multicolumn{3}{|c|}{ Numerical values } \\
\hline 1 & pH, ед. pH & \multicolumn{2}{|c|}{$7,2-7,6$} & 6,7 \\
\hline 2 & $\mathrm{BOD}_{5}, \mathrm{mgO}_{2} / \mathrm{dm}^{3}$ & \multicolumn{2}{|c|}{$120-280\left(200^{*}\right)$} & 9012 \\
\hline 3 & $\mathrm{COD}, \mathrm{mgO}_{2} / \mathrm{dm}^{3}$ & \multicolumn{2}{|c|}{$420(350)$} & 18928 \\
\hline 4 & Oxidation, $\mathrm{mgO}_{2} / \mathrm{dm}^{3}$ (perm.) & \multicolumn{2}{|c|}{$35-120$} & 11335 \\
\hline 5 & Suspended substance, $\mathrm{mg} / \mathrm{dm}^{3}$ & \multicolumn{2}{|c|}{$300-416(200)$} & 5154 \\
\hline 6 & $\mathrm{HCO}_{3}^{-}, \mathrm{mg} / \mathrm{dm}^{3}$ & \multicolumn{2}{|c|}{-} & 859,0 \\
\hline 5 & $\mathrm{NH}_{4}^{+}, \mathrm{mg} / \mathrm{dm}^{3}$ & $60-130$ & \multirow{3}{*}{$(19-60)$} & 156,0 \\
\hline 7 & $\mathrm{NO}_{3}^{-}, \mathrm{mg} / \mathrm{dm}^{3}$ & - & & 1,3 \\
\hline 8 & $\mathrm{NO}_{2}^{-}, \mathrm{mg} / \mathrm{dm}^{3}$ & - & & $<0,02$ \\
\hline 9 & $\mathrm{SO}_{4}^{2-}, \mathrm{mg} / \mathrm{dm}^{3}$ & \multicolumn{2}{|c|}{-} & $<2,0$ \\
\hline 10 & $\mathrm{Cl}^{-}, \mathrm{mg} / \mathrm{dm}^{3}$ & \multicolumn{2}{|c|}{$70-90$} & 251,0 \\
\hline 11 & $\mathrm{PO}_{4}^{3-}, \mathrm{mg} / \mathrm{dm}^{3}$ & \multicolumn{2}{|c|}{$12,5-16,0$} & 35,4 \\
\hline 12 & $\mathrm{H}_{2} \mathrm{~S}, \mathrm{mg} / \mathrm{dm}^{3}$ & \multicolumn{2}{|c|}{-} & 1,3 \\
\hline 13 & $\mathrm{Fe}^{2+}+\mathrm{Fe}^{3+}, \mathrm{mg} / \mathrm{dm}^{3}$ & \multicolumn{2}{|c|}{-} & 18,5 \\
\hline 14 & $\mathrm{Ca}^{2+}, \mathrm{mg} / \mathrm{dm}^{3}$ & \multicolumn{2}{|c|}{ - } & 117,9 \\
\hline 15 & $\mathrm{Mg}^{2+} \mathrm{mg} / \mathrm{dm}^{3}$ & \multicolumn{2}{|c|}{-} & 30,6 \\
\hline 16 & $\mathrm{Na}^{+} \mathrm{mg} / \mathrm{dm}^{3}$ & \multicolumn{2}{|c|}{ - } & 154,5 \\
\hline 17 & $\mathrm{~K}^{+} \mathrm{mg} / \mathrm{dm}^{3}$ & \multicolumn{2}{|c|}{25,0} & 8,4 \\
\hline
\end{tabular}


3. It is necessary to introduce the studies on the chemical analysis of groundwater in the practice of geo-ecological research, using an extended set of components with a mandatory study of the organic content by values of $\mathrm{COD}$ and $\mathrm{BOD}_{5}$. In addition, it is important to perform a chemical analysis of water in the first hours to obtain reliable data on its composition.

4. It is necessary to improve the existing system for monitoring the state of groundwater, which should include: 1) the study of changes in the hydro-chemical mode and level of groundwater in terms of their impact on the stability of buildings and aggressiveness relative to materials of underground structures; 2 ) assessment of the state of the aeration zone and the accumulation of contaminating agents therein; 3 ) monitoring the formation of banked-up water level in the zones of possible leaks from water disposal systems and, accordingly, the changes in the chemical composition of groundwater; 4) assessment of the impact of floods on the self-purification processes of the aeration zone, groundwater and its dynamics.

\section{REFERENCES}

1. Abouzar Nasiri, Vera A. Shirocova and Sajad Zareie. 2019. Zoning of Groundwater Quality for Plain Garmsar in Iran. Journal of water recourse, 46(4), 624-629.

2. Boikov A V, Payor V A, Savelev R V. 2018. Technical vision system for analysing the mechanical characteristics of bulk materials. Journal of Physics Conference Series. 944, 1-6.

3. Chupin, S., Bolobov, V. 2018. Influence of thermomechanical treatment modes on wear resistance of mining equipment material. Materials Science Forum Russia, 695-699.

4. Code of practice 11-102-97. Engineering and environmental surveys for construction. Moscow, Gosstroy of Russia, GUP CPP, 2001, 38 p (in Russia).

5. Dashko R., Karpova Ya. 2015. Underground space of saint-petersburg as a multicomponent system: Engineering geological and geotechnical aspects of its development. International Multidisciplinary Scientific GeoConference Surveying Geology and Mining Ecology Management, SGEM, 2(1), 827-83.

6. Dashko R.E. and Shidlovskay A.V. 2016. Impact of microbial activity on soil properties. Canadian Geotechnical Journal, 53(9), 1386-1397.
7. Ecological situation in the Krasnogvardeisky district Saint Petersburg. Report from Environmental Committee Committee and Ensuring Environmental Safety of St. Petersburg. 2017. Available at: https.:/www.gov.spb.ru/static/writable/ckeditor/ uploads/2017/11/13/ krasnogvardeisky.pdf. (in Russia).

8. Escudero, C., Vera, M., Oggerin, M., Amils, R. 2018. Active microbial biofilms in deep poor porous continental subsurface rocks. Scientific Reports, 8 (1), article № 1538 .

9. Golovina, E.I. 2017. Strategic issues groundwater extraction management in Russia, Journal of Ecological Engineering. 18 (3), 13-21.

10. Gorskaya V.A. Engineering-geological analysis of the historical aspect of the development and contamination of the underground space of St. Petersburg. Candidate of diss. [Engineering and geological analysis of the historical aspect of the development and contamination of the underground space St. Petersburg Ph.D.]. St. Petersburg, 2017, 250 p.

11. Griebler, C., Lueders, T. 2009. Microbial biodiversity in groundwater ecosystems Freshwater Biology, 54 (4), pp. 649-677.

12. Gukovskiy Yu.L., Sychev and Yu.A. Pelenev D.N. 2017. The automatic correction of selective action of relay protection system against single phase earth faults in electrical networks of mining enterprises. International Journal of Applied Engineering Research, V.12, 833-838.

13. Humphreys, W.F. 2009. Hydrogeology and groundwater ecology: Does each inform the other? Hydrogeology Journal, 17 (1), 5-21.

14. Iakovleva E. V., Belova M. V., Popov A. L.2019. Mining and Environmental Monitoring at Open-Pit Mineral Deposits. Journal of Ecological Engineering, 20 (5), 172-178.

15. Korbel, K., Chariton, A., Stephenson, S., Greenfield, P., Hose, G.C. 2017. Wells provide a distorted view of life in the aquifer: Implications for sampling, monitoring and assessment of groundwater ecosystems Scientific Reports, 7, article № 40702.

16. Lin, X., McKinley, J., Resch, C.T., Kaluzny, R., Lauber, C.L., Fredrickson, J., Knight, R., Konopka, A. 2012. Spatial and temporal dynamics of the microbial community in the Hanford unconfined aquifer. ISME Journal, 6 (9), 1665-1676.

17. Mihail, M., Isheyskiy, V., Vadim, D. 2018. Drilling and blasting influence on the process of dust particles formation International Journal of Mechanical Engineering and Technology, 9 (12), 97-103.

18. Nefedov Y. V., Klepikov I. V. 2018. Occurrence Regularities of Nitrogen Defects in the Ural Type Crystal Diamonds from Different Regions /Key Engineering Materials, V 769, 201-206.

19. Nikolaev A.K, G H Samigullin, L G Samigullina, 
V G Fetisov. 2017. Non-stationary operation of gas pipeline based on selections of travel. IOP: Materials Science and Engineering, V.327, 1-5.

20. Shashkin, A.G., Shashkin, K.G., Dashko, R.E. 2019. Analysis of causes of deformations in historic buildings on weak clay soils, Geotechnics Fundamentals and Applications in Construction: New Materials, Structures, Technologies and Calculations - Proceedings of the International
Conference on Geotechnics Fundamentals and Applications in Construction: New Materials, Structures, Technologies and Calculations, GFAC 2019, 329-334.

21. Trushko, O.V., Potemkin, D.A., Popov, M.G. 2018. Ensuring sustainability of mining workings in development of ore deposits in complex geological conditions. ARPN Journal of Engineering and Applied Sciences, 13(7), 2594-2601. 